\title{
Stomach cancer mortality in Spain: an ecological analysis of diet, altitude, latitude, and income
}

\author{
Jesús Vioque, Cayetano Merino Egea, Miquel Porta
}

\section{Departamento de Salud Pública, Universidad de Alicante, Ap. correos 374, E-03080, Alicante, Spain $\mathrm{J}$ Vioque \\ Instituto Valenciano de Estudios en Salud Pública (IVESP), Valencia, Spain J Vioque \\ C M Egea}

Instituto Municipal de Investigación Médica, Universidad

Autónoma de

Barcelona, Barcelona,

Spain

M Porta

Correspondence to: Dr J Vioque.

Accepted for publication February 1995

(F Epidemiol Community Health 1995;49:441-442)
The decline over the past decade in the incidence and mortality from stomach cancer has been documented in numerous studies carried out in different parts of the world. Stomach cancer, however, still causes a high number of deaths in Spain. ${ }^{1}$ The geographical distribution of stomach cancer varies greatly. In general, it shows a higher incidence in poorer, more northerly regions, located at higher altitudes. ${ }^{2}$ Among the different factors that have been studied in relation to this peculiar distribution, the diet is considered to play a critical role.

This study was aimed to determine whether in recent years mortality from stomach cancer in provinces in Spain was related to the geographical distribution of the income level, mean altitude and latitude of each province, and the distribution of suspected dietary risk factors such as a low intake of fresh fruits and vegetables.

Risk of gastric cancer in relation to the per capita income, altitude, latitude, and consumption of fruit, vegetables, calories, and vitamins $C$ and $A$ in Spanish provinces

\begin{tabular}{|c|c|c|c|c|}
\hline Variable & $\begin{array}{l}\text { Exposure by } \\
\text { quintile }\end{array}$ & $\begin{array}{l}\text { Crude } \\
R R^{*}(95 \% C I)\end{array}$ & $\begin{array}{l}\text { Adjusted } \\
R R+(95 \% C I)\end{array}$ & $\begin{array}{l}\chi^{2} \text { trend } \\
(p \text { value }) \ddagger\end{array}$ \\
\hline $\begin{array}{l}\text { Per capita } \\
\text { Income } \\
\text { (000s pesetas) }\end{array}$ & $\begin{array}{l}260-297 \\
298-314 \\
315-337 \\
338-393 \\
394-468\end{array}$ & $\begin{array}{l}1 \\
0.95(0.92,0.98) \\
1.10(1.06,1.14) \\
0.93(0.90,0.96) \\
0.80(0.79,0.93)\end{array}$ & $\begin{array}{l}1 \\
0.90(0.86,0.93) \\
0.85(0.81,0.88) \\
0.69(0.66,0.72) \\
0.63(0.61,0.66)\end{array}$ & $\begin{array}{l}-23 \cdot 1 \\
(p<0 \cdot 001)\end{array}$ \\
\hline $\begin{array}{l}\text { Altitude } \\
(\mathrm{m})\end{array}$ & $\begin{array}{c}15-44 \\
45-142 \\
143-458 \\
459-691 \\
692-1131\end{array}$ & $\begin{array}{l}1 \\
1.08(1.05,1.11) \\
1.15(1.12,1.19) \\
1.04(1.00,1.07) \\
1.64(1.58,1.69)\end{array}$ & $\begin{array}{l}1 \\
0.90(0.87,0.93) \\
0.98(0.95,1.02) \\
0.99(0.96,1.03) \\
1.17(1.12,1.11)\end{array}$ & $\begin{array}{l}-8 \cdot 1 \\
(p<0 \cdot 005)\end{array}$ \\
\hline $\begin{array}{l}\text { Latitude } \\
(\% / \mathrm{min})\end{array}$ & $\begin{array}{l}<38^{\circ} \\
-39^{\circ} 85^{\prime} \\
-41^{\circ} 42^{\prime} \\
-42^{\circ} 24^{\prime} \\
-43^{\circ} 17^{\prime}\end{array}$ & $\begin{array}{l}1 \\
1.14(1.10,1.18) \\
1.11(1.08,1.15) \\
1.23(1.19,1.27) \\
1.36(1.32,1.41)\end{array}$ & $\begin{array}{l}1 \\
1.30(1.26,1.35) \\
1.39(1.32,1.45) \\
1.74(1.66,1.83) \\
1.70(1.62,1.77)\end{array}$ & $\begin{array}{l}-24.4 \\
(p<0.001)\end{array}$ \\
\hline $\begin{array}{l}\text { Fruits } \\
\text { (kg/person/d) }\end{array}$ & $\begin{array}{l}173-263 \\
264-281 \\
282-292 \\
293-306 \\
307-324\end{array}$ & $\begin{array}{l}1 \\
0.98(0.95,1.01) \\
0.93(0.90,0.96) \\
0.79(0.77,0.81) \\
0.86(0.84,0.89)\end{array}$ & $\begin{array}{l}1 \\
0.97(0.93,1.00) \\
0.95(0.92,0.99) \\
0.85(0.82,0.88) \\
0.91(0.88,0.95)\end{array}$ & $\begin{array}{l}-14.69 \\
(p<0.001)\end{array}$ \\
\hline $\begin{array}{l}\text { Vegetables } \\
(\mathrm{kg} / \text { person/d) }\end{array}$ & $\begin{array}{l}242-311 \\
312-333 \\
334-393 \\
394-438 \\
439-960\end{array}$ & $\begin{array}{l}1 \\
0.73(0.71,0.76) \\
0.65(0.63,0.67) \\
0.64(0.62,0.66) \\
0.78(0.76,0.81)\end{array}$ & $\begin{array}{l}1 \\
1.01(0.96,1.05) \\
0.86(0.81,0.91) \\
0.86(0.82,0.91) \\
0.88(0.83,0.93)\end{array}$ & $\begin{array}{l}-7 \cdot 28 \\
(p<0 \cdot 01)\end{array}$ \\
\hline $\begin{array}{l}\text { Energy } \\
\text { (kc/person/d) }\end{array}$ & $\begin{array}{l}<2928 \\
2929-3108 \\
3109-3223 \\
3224-3353 \\
3354-4723\end{array}$ & $\begin{array}{l}1 \\
1.14(1.11,1.17) \\
1.22(1.19,1.26) \\
1.32(1.28,1.36) \\
1.41(1.38,1.45)\end{array}$ & $\begin{array}{l}1 \\
1.06(1.03,1.10) \\
1.10(1.06,1.14) \\
1.07(1.03,1.12) \\
1.06(1.02,1.10)\end{array}$ & $\begin{array}{l}-3.56 \\
\text { (N.S.) }\end{array}$ \\
\hline $\begin{array}{l}\text { Vitamin C } \\
(\mathrm{mg} / \text { person/d) }\end{array}$ & $\begin{array}{l}105-119 \\
120-127 \\
128-135 \\
136-144 \\
145-232\end{array}$ & $\begin{array}{l}1 \\
0.73(0.71,0.76) \\
0.84(0.81,0.87) \\
0.66(0.63,0.68) \\
0.61(0.59,0.63)\end{array}$ & $\begin{array}{l}1 \\
1.00(0.96,1.04) \\
0.89(0.86,0.93) \\
0.85(0.82,0.89) \\
0.79(0.76,0.82)\end{array}$ & $\begin{array}{l}-14.69 \\
(p<0.001)\end{array}$ \\
\hline $\begin{array}{l}\text { Vitamin A } \\
\text { (IU/person/d) }\end{array}$ & $\begin{array}{l}582-659 \\
660-696 \\
697-730 \\
731-783 \\
784-975\end{array}$ & $\begin{array}{l}1 \\
0.93(0.90,0.97) \\
0.78(0.76,0.81) \\
0.73(0.71,0.75) \\
0.70(0.69,0.72)\end{array}$ & $\begin{array}{l}1 \\
1.02(0.97,1.06) \\
1.11(1.06,1.16) \\
0.94(0.91,0.98) \\
0.93(0.89,0.96)\end{array}$ & $\begin{array}{l}-5.86 \\
(p<0.01)\end{array}$ \\
\hline
\end{tabular}

${ }^{*} R R$, relative risk. The reference category is the SMR for the first quintile. $\dagger$ In addition to the variable of interest, each model also included per capita income, latitude and
altitude.

$\ddagger \mathrm{p}$ value for the $\chi^{2}$ test with 1 clf; $\mathrm{NS}=$ non-significant

Methods: Stomach cancer data (ICD, 9th revision - 151) between 1981 and 1986 for the 50 Spanish provinces were obtained from registers of the National Institute for Statistics (Instituto Nacional de Estadística). Standardised mortality ratios (SMR) for every province were estimated as the ratio of observed to expected deaths. Expected numbers of deaths in each province were obtained by applying age specific death rates for the whole of Spain to the corresponding population by age and sex. Data on variables related to food consumption were obtained from a large, population based survey $(n=24000)$ conducted in 1981. Unfortunately, data on salt consumption were not available from the food survey. Data on altitude, latitude, and per capita income were obtained from national statistical sources.

Poisson regression analysis (GLIM computer program) was used to calculate the effects of the independent variables based on the following model:

$$
\log \lambda=\log N+\beta_{o}+\beta_{i} X_{i}+\varepsilon ;
$$

where $\lambda$ is the number of deaths from stomach cancer reported in each province; $N$, the number of expected deaths for each province; the exponential of $\beta_{o}$, the SMR of reference, the lower exposure quintile; and the exponential of $\beta_{i}$, the effect of the variable of interest. Univariate and multivariate models were adjusted to explore the effects of variables.

Results: The crude effect of each independent variable is shown in the table. The per capita income showed a negative association with mortality from stomach cancer; mortality among provinces with the highest levels of income was $20 \%$ lower than in provinces with the lowest levels of income. A positive association with altitude was also found, and latitude was also positively associated with mortality from stomach cancer.

The consumption of fruit and vegetables was negatively associated with stomach cancer. Provinces in the upper quintile showed $14 \%$ and $22 \%$ reductions respectively in mortality compared with those in the lowest quintile of consumption. A positive association was observed between stomach cancer mortality and total calory intake. A clear negative (inverse) association was also observed between mortality and the consumption of vitamins A and $\mathrm{C}$. The association was stronger for the latter. The SMRs were 39\% lower in the provinces that consumed most vitamin $\mathrm{C}$ compared with provinces that consumed least (lowest quintile). 
To determine whether the relationships observed between stomach cancer mortality and the non-dietary variables were independent, a model including altitude, latitude, and per capita income, and the dietary variables was fitted (table). Both the negative association between gastric cancer mortality and per capita income, and the positive association with latitude observed in the crude analysis were enhanced, whereas the positive association initially found with altitude became weaker. The protective effect of the consumption of fruit and vegetables diminished in the multivariate analysis, although a statistically significant, negative association with mortality persisted. The negative association between consumption of vitamin $\mathrm{C}$ and mortality from stomach cancer observed in the crude analysis persisted, although somewhat reduced. The effects of calory and vitamin A consumption were weaker when adjusting for income, altitude, and latitude.

Discussion: In the present study, data aggregated at the provincial level yielded a negative association between mortality from stomach cancer and level of income, consumption of vitamin $C$, and consumption of fruit and vegetables. Moreover, a positive association between mortality and latitude was found. Other associations initially observed in the crude analysis (altitude, calories, and vitamin A) were substantially reduced in the multivariate analyses. These results are unlikely to have been due to regional variation in registration efficiency, in spite of the fact that validity may be compromised in ecological studies when several SMRs are compared with each other. The main aim, however, of the study was not the direct comparison of SMRs but the estimation of the effect at the provincial level of the independent variables to see whether the distribution of the disease could be partly explained by the distribution of considered risk factors. In addition, the results obtained in this study are consistent with those obtained in other studies, ${ }^{3-5}$ in particular, the negative association observed between mortality from stomach cancer and the consumption of vitamin $C$, fruit, and vegetables. This study supports previous evidence indicating that recommendations on the consumption of fruit and vegetables will further speed the reduction in mortality from stomach cancer.

This work was partially funded by Fondo de Investigación Sanitaria (grant 91/0435) and by the Instituto Valenciano de Estudios en Salud Pública (IVESP - 1991). The authors thank Andrew R Maguire for thoughtful comments to earlier versions of this manuscript and Dr Marta Pulido for editorial assistance and copy editing.

1 Bolumar F, Vioque J, Cayuela A. Changing mortality patterns for major cancers in Spain, 1951-1985. Int $\mathcal{f}$ Epidemiol 1991;20:1-6.

2 Cayuela A, Vioque J, Rodríguez-Arce A, Rojas M, JiménezMengibar C. Diferencias geográficas de la mortalidad por tumores digestivos en España, 1980-1984. Gac Sanit 1991; 23:72-81.

3 Steinmetz KA, Potter JD. Vegetables, fruit, and cancer I. Epidemiology. Cancer Causes Control 1991;2:325-357.

Archer VE. Latitudinal variation of digestive tract cancers in the US and China. Nutr Cancer 1989;12:213-223.

5 Barker DJP, Coggon D, Osmond C, Wickham C. Poor housing in childhood and high rates of stomach cancer in England and Wales. Br $₹$ Cancer 1990;61:575-578. 